\title{
Socio-Economic Impact of Cluster Marketing: The Case of Ned Landcare Association Sweet Pepper Cluster
}

\author{
J.T. Axalan, F.T. Israel and S.B. Concepcion \\ University of the Philippines in Mindanao \\ The Philippines \\ P.J. Batt and R. Murray-Prior \\ Curtin University \\ Australia \\ L. Loma \\ Landcare Foundation of the Philippines Inc \\ The Philippines
}

Keywords: cluster marketing, sweet pepper, land care association

\begin{abstract}
Through clustering, opportunities exist for smallholder farmers to organize their output and to sell directly to institutional markets. This paper analyses the experiences of the cluster marketing approach in Barangay Ned, Lake Sebu, South Cotabato. The case demonstrates how farmers in the cluster group developed an enterprise plan, established linkages with a microfinance institution and negotiated sales to downstream market intermediaries. Farmers in the cluster increased their technical and marketing knowledge, improved their farming and marketing practices, improved their access to capital and increased their income. Trust, confidence, commitment and unity among cluster members were established through the cluster marketing approach.
\end{abstract}

\section{INTRODUCTION}

About 5.7 million households in the Philippines are involved in vegetable production, where the majority of smallholder farmers (80\%) earn less than $\mathrm{PhP} 3,000$ per month (Batt, 2007). While a number of regions in the Philippines produce fresh vegetables, smallholder producers are generally unable to meet the requirements of downstream buyers for quality and continuity of supply. Opportunities exist for farmers to organize their supply into larger more marketable volumes and to sell directly to institutional markets.

One of the approaches to facilitate the supply of a more consistent volume of quality vegetables is through the clustering approach, where a small group or cluster is organized and guided to engage the market to improve their incomes and livelihood (CRS-Philippines, 2007). Such collaborative marketing arrangements typically provide farmers with more market knowledge, more negotiating power and a higher price and may have a significant positive impact on the farmers' income.

This paper analyses the experience of the Ned Landcare Cluster Association, a group of smallholder farmers in Barangay Ned, Lake Sebu, South Cotabato, who went through the process of organizing a marketing cluster for their products. It identifies the 
socio-economic impacts of the clustering approach and key success factors learned from their experiences in cluster marketing.

\section{BARANGAY NED}

Barangay Ned is situated in the north western part of the Municipality of Lake Sebu, in the province of South Cotabato. Ned is approximately $100 \mathrm{~km}$ from Koronadal City, the province's capital. Ned has approximately 41,247 ha of land, divided into 32 sitios at an average elevation of $800-900 \mathrm{~m}$ above sea level. It is populated by more than 15,378 people who mostly depend on farming for their main source of income (Batt, 2007). The population was dominated by Ilonggo (80\%), with T'boli making up $15 \%$ and Cebuano 5\% (Cramb, 2003)

The topography is rolling to mountainous with some areas of arable plateau, although the northern margins are characterized by gently rolling terrain and valleys. Rivers, creeks and streams abound. The area has abundant surface and groundwater and is generally well drained. The soils are predominantly neutral to acidic sandy-loams with a clay B horizon, of low to moderate fertility which are highly susceptible to erosion. The only road into Ned is via a former logging road and a network of trails traversed on foot or horseback (Cramb, 2003). The road is narrow, unsurfaced and often impassable during the wet periods of the year.

\section{METHODS}

The majority of information for this study was sourced from personal interviews and focus group discussions with farmers during the agro-enterprise activities conducted with the farmers in the Ned cluster. The agro-enterprise activity revolves around the eight steps of the CRS-Philippines clustering approach, which employs a participatory action learning process. The main objective of the process is to improve the livelihoods of farmers by linking them with institutional buyers and service providers. The process is supported by providing on-going technical support in the production of fresh produce that meets the requirements of these buyers. This includes advice on pest and disease control, variety selection and post-harvest procedures necessary to meet the desired quality, volume and reliability requirements. The process was facilitated by the Landcare Foundation Philippines Inc (LFPI), Catholic Relief Services (CRS) and UP Mindanao.

\section{DEVELOPMENT OF THE NED CLUSTER}

Before development organizations came to Barangay Ned, farmers were growing corn, rice, vegetables and peanuts for household consumption. Farmers were not organized and sold their surplus products individually to wholesale buyers. Some farmers, whose production inputs were financed by traders, had no option but to sell their produce to the financier, despite the lower price offered for it.

In 1999, the Ned farmers became members of the Ned Landcare Association Inc (NLCA), which is a farmers organization facilitated by the Philippine-Australia Landcare Project. NLCA had approximately 400 members organized into 35 sub-groups in 30 sitios. Around $60 \%$ were practicing conservation farming on $30 \%$ of the land area (Batt, 2007).

In 2003, some members of NLCA shifted from corn to vegetable production in the hope of higher returns as the costs of cultivating corn increased and transport costs increased to bring their produce to Sto. Niño or Isulan. These vegetables included sweet pepper and carrots. However, the organization had few market linkages and marketing 
strategies at that time. They established and developed a "suki system" as their local marketing outlet, in which cooperatives in the sitios and neighbouring farmers were the most prevalent market outlet for the members.

NLCA began to progress when they linked with the Catholic Relief Service (CRS) which, in partnership with LFPI, introduced the eight step clustering approach to the farmers in 2007. The Association selected 16 Landcare members to serve as the pilot cluster for vegetable agro-enterprise development in 2008. Two training workshops were conducted in February 2008, followed by negotiations with buyers and linkages with a microfinance institution were established. From these activities, the cluster was able to formulate and execute their agro-enterprise plan, choosing sweet pepper as the initial crop. According to the cluster members, sweet pepper was selected because there was a ready market, the area was suitable for sweet pepper production, the crop is easy to manage, it can be harvested weekly after only three months and can be subsequently harvested for up to eight months. Furthermore, the majority of NLCA members were already growing sweet pepper. Cluster members also shared a common goal to take good care of their land. One requirement to become a cluster member is that farmers must practice conservation farming through contour planting.

After six months of operation, 32 deliveries had been made totalling 47,155 kg of sweet pepper, with a gross income of $\mathrm{PhP} 1.3$ million. After deducting marketing costs, each farmer received around $\mathrm{PhP}$ 19,778 from cluster marketing. The NLCA also benefited financially, for a marketing levy of $\mathrm{PhP} 0.50$ per $\mathrm{kg}$ was applied to all crops sold through the cluster. From July 2009 to December 2009, the cluster's deliveries to their buyers increased to 79,241 kg. The average monthly price ranged from $\mathrm{PhP} 19.00$ 41.00 per $\mathrm{kg}$. Some $55 \%$ of their produce went to various consolidators serving a large tuna canning processor, while $45 \%$ went to local buyers in Isulan, Koronadal and Davao. By January 2010, the membership had expanded to 36 members.

\section{SOCIO- ECONOMIC IMPACTS}

Although the marketing cluster in Ned remains in its infancy, the group has had some impact on the cluster members in terms of their social and economic wellbeing.

\section{Changes in Farmer Knowledge}

The exposure of Ned farmers to buyers beyond their local areas had an immediate impact on their knowledge and ambitions. When the farmers realised the importance of cluster formation in linking with institutional buyers to meet product quantity and quality requirements, they became more pro-active and interested in finding more information on how to improve quality from seed selection to post-harvest handling.

During their meetings they discussed; (i) problems and alternative solutions for each delivery; (ii) the financial reports; (iii) assignment of marketing officers for specific weeks and months; (iv) the production area and the expected date and volume of harvest; and (v) reviewed and revised their constitution.

Before the formation of the cluster, Ned farmers sold their product directly to traders at Lambak or Isulan. They had little knowledge of the market requirements and often believed that they were being deceived by the traders. For example, local markets preferred to buy mature green sweet pepper, whereas the tuna canning company bought red sweet pepper for a higher price. Through a market chain analysis, farmers learned where to sell the green fruit and the red fruit in order to maximise market returns. 
Cluster members are now providing training to other farmers not currently part of the cluster. Fourteen additional NLCA members and 17 non members have asked for technical assistance from the cluster members and are now growing sweet peppers. The non members were encouraged to join the cluster.

\section{Changes in Farmer Practices}

Before the introduction of agro-enterprise training, Ned farmers were planting small areas of vegetables and selling them to local markets, neighbours or to middle men in Lambak, Gapok or Isulan. Most of the time, they sold sweet pepper at prices ranging from PhP 8-10 per $\mathrm{kg}$ in Lambak and PhP 15-25 per kg in Isulan. Farmers had some knowledge of the reason for the price differences between these various markets, but they were not aware of the large differences in price between the classifications of red, green and off-size fruit.

After a number of training sessions and visits, Ned farmers and partners from Lake Seloton, became more aware of the importance of capacity building within their organization and of the need to achieve a sufficient volume of production and quality to meet their customer's expectations. In order to improve the quality of the sweet pepper produced, changes on-farm were made to: (i) cultivate a superior variety; (ii) improve pest and disease management; (iii) more judiciously apply fertilisers; (iv) improve postharvest handling; and (v) the use of plastic mulch. Farmers reported that they had previously planted whatever seeds were available locally. Farmers are now planting the Cayenne Premium variety and have expanded the number of hills significantly.

\section{Changes in Marketing Practices}

As the farming systems in Ned changed, so also did the marketing arrangements. In the past, Ned farmers received cash payments for their produce and often cash advances to purchase inputs. They were then expected to sell to their suki at a lower price and had little opportunity to negotiate.

Ned farmers were given some basic training as to how to conduct a market chain study and to interview potential buyers to obtain information about their requirements. Role playing was used for the members to practice their interview skills before visiting the markets. Farmers interviewed local buyers in wet markets in Surallah and also visited institutional buyers such as supermarkets and restaurants in Koronadal City and General Santos. A group of farmers met with the purchasing manager and owner of a vegetable commercial centre in Koronadal City and asked questions regarding product quality and quantity requirements, the mode of payments and processes. They also met with one of the consolidators for a tuna canning company with regard to exploring a possible partnership. The tuna canning company required 15-20 tonnes of red sweet pepper per week. They traditionally purchased vegetables from suppliers (consolidators) in General Santos. However, the demand for sweet pepper also depended on the availability of carrots and potatoes (joint demand). After returning from the market study, the group reported back to the cluster.

In February 2008, the cluster members met with the consolidator to discuss a trial delivery of sweet peppers. The group clarified the volume and quality requirements, the price to be paid, the schedule of delivery and mode of payment. A trial delivery was made in August 2008, with $138 \mathrm{~kg}$ of sweet peppers delivered to the consolidator. They delivered regularly until November 2008 when the consolidator dishonoured them by issuing several cheques which bounced in payment for their produce. This became an 
issue for the group because they had already incurred harvesting, post-harvest and marketing expenses, as well as interest on their loans, in order to make the delivery. With little working capital, the group could not easily absorb the cash flow fluctuations and tried to negotiate partial payment on delivery. The cluster also met with ICTUS, a member-owned cooperative that provided savings and lending services, including financing inputs, to discuss the outcome of the test marketing and the payment with postdated cheques. ICTUS agreed to cash the post-dated cheques issued by the consolidator if the cluster would open an account with ICTUS. However, their experiences with the consolidator caused them to look for other buyers. They learned to look for buyers that were more committed and trustworthy. Their enterprise plan was revised for the second cycle of planting and they were successful in supplying their products to other consolidators of the tuna canning company. The cluster also supplied to other alternative local buyers in Koronadal City, Isulan, Sultan Kudarat and in Davao City.

\section{Improved Access to Financial Capital}

The cluster members met with ICTUS and obtained a financial loan for the purchase of inputs for its members. In order to get a loan, the cluster members had to first become a member of the bank and attend a pre-membership seminar. A membership fee and initial savings of $\mathrm{PhP} 1,700$ had to be deposited by each farmer. Of the 18 cluster members, only four could afford this initial cost. As the remainder were able to find half the amount, the LFPI contributed sufficient funds to meet the short fall. A loan was released to the members of the cluster for PhP 10,000 per farmer.

\section{Increased Farmers' Income}

Some individual cluster members have seen their household income increase by $100-200 \%$ as a result of shifting from corn to sweet pepper. This has enabled them to purchase a number of things including sala sets, carabao, back pack sprayers, a mini rice mill and to complete a new house. Since the beginning of the process, 5 cluster members have purchased mobile phones and learnt how to use SMS to communicate and negotiate with buyers regarding the prevailing prices for their produce. Three members said they were able to send their children to college and six members said that the income from sweet peppers had facilitated the education of their children. Some of the farmers were able to close long standing debts with relatives.

\section{Increased Employment in the Community}

Beyond the cluster members, the increase in vegetable production generated more employment opportunities for planting, weeding, harvesting and sorting. It is estimated that, on average, each cluster member now requires an additional five man days per week to accommodate the activities associated with sweet pepper production. The motorbike (skylab) drivers who transport the sweet pepper to St Nino and the van drivers who then take the produce to General Santos have also increased their income. "Skylab" drivers in Ned are paid $\mathrm{PhP} 200$ per sack to transport the fruit. The marketing officer is also paid for their time $(\mathrm{PhP} 0.5 / \mathrm{kg})$ with the position rotating among the members.

\section{Additional Benefits to Members}

There have already been some significant impacts for the cluster members beyond the changes in knowledge and practices: 
- $\quad$ members have the confidence to negotiate with buyers and other service providers such as ICTUS;

- $\quad$ marketing expenses are now shared between the members;

- members report that they can now donate sweet peppers to neighbours during celebrations;

- $\quad$ cluster members are also providing training to other farmers not currently part of the cluster. Fourteen additional NLCA members and 17 non members have asked for technical assistance from the cluster members and are now growing sweet peppers;

- $\quad$ Ned cluster members are in the process of expanding the production area of bell pepper for bigger markets while at the same time maintaining the fertility of the soil, following contour farming practices and using naturally produced pesticides and insecticides. To maximize the productivity of their vegetable area, 17 farmers planted rubber and fruit trees along the contour lines at a suitable spacing so sunlight could still penetrate.

\section{KEY LESSONS}

The success of the Ned clusters can be attributed to several factors including the presence of social capital, different markets and financial institutions, the terrain and the cohesiveness of the group.

Much of the success of the Ned cluster is credited to the presence of social capital, perhaps as a result of the presence of Landcare in the area. The relationship between the Landcare facilitators and local government units has helped link the Ned farmers to other institutions. The Office of the Provincial Agriculturalist (OPAG) noted that as Landcare has evolved from soil and water conservation to production and more recently marketing, it has maintained good linkages with other institutions such as the OPAG, whereas other projects have often failed to consult the Local Government Unit (LGUs).

Working with existing Landcare farmers, much of the social capital needed for cluster marketing already exists. Hence, the initial inputs for organisational development are reduced. According to the CRS staff, the Landcare groups are well organised with high existing levels of social capital, making facilitation easier. They see the farmers as already having good production skills, but are willing to try new things. It is recognised by all the partner institutions that the existing social capital established in the proceeding phases of the project has allowed the agro-enterprise process to work most efficiently, compared to other instances where farmer groups must first be established.

The presence of several markets for their products has also contributed to the success of the cluster. Such a diversity of markets provides farmers with numerous outlets for their vegetables. When the supply of carrots and potatoes is low, the demand for sweet pepper also decreases from the tuna canning factory, hence farmers had to find other markets for their produce. In addition to the tuna canning factory, cluster members are delivering sweet pepper to local buyers in Davao and a major supermarket in General Santos.

The Ned Landcare farmers have a history of working together, sharing knowledge and adapting farming practices to suit the local conditions. It is acknowledged that the farmers already help one another with farm activities and exchange information about how best to grow their crops, who their buyers are, as well as participating in other social activities. Landcare farmers have had a long history of receiving technical support 
through group-based processes and adapting and sharing technologies. Their success can be attributed to their maturity and their ability to learn easily from their experiences, especially from their mistakes. For example, their experiences with the consolidator caused them to look for other buyers who were more committed and trustworthy.

They updated their operational policies based on their actual experiences in production and marketing. Around $90 \%$ of the cluster members participate in every meeting, despite the distance between their farms. This behaviour has led to the greater implementation of policies.

Due to the distances involved, marketing in Barangay Ned remains constrained by it remoteness and inaccessibility, particularly during wet periods when the road often becomes impassable. While the cluster has been unable to improve the roads, the farmers have utilised multiple modes of transport to move the product and constructed a packing shed at the point where the product is ultimately transferred to the buyer, enabling them to remove any product which has been damaged in transit.

\section{CONCLUSION}

The cluster marketing approach adopted by the Ned Landcare Cluster Association may be a good model for other smallholder farmer groups. The farmers in the cluster have learned to develop their enterprise plan, to establish linkages with a microfinance institution, and to negotiate terms of trade with institutional buyers and other partners. Farmers have increased their technical and marketing knowledge, improved their farming and marketing practices, improved their access to capital, and increased their income. Capacity among cluster members has gradually improved. Cluster members can facilitate meetings without the presence of local partners and maintain and update their financial management and recording system. They have developed a planting schedule and some are recording farm expenses and income.

The benefits of clustering have provided income not only for the farmers but also for the entire community. Trust, confidence, commitment and unity among cluster members have been established through the cluster marketing approach.

The success of Ned can be replicated if several key success factors are present: high existing levels of social capital; the presence of several competing markets; microfinance is readily available; and the group share a common belief - the desire to work together and to share knowledge.

\section{ACKNOWLEDGEMENTS}

This paper is part of the results of the research project entitled "Component 4: Enhancing the profitability of selected vegetable value chains in Southern Philippines and Australia funded by the Australian Centre for International Agricultural Research.

\section{Literature Cited}

Batt, P.J. 2007. Enhanced profitability of selected vegetable value chains in the southern Philippines and Australia: Component 4: Analysis of selected value chains in the southern Philippines, Component Proposal HORT/2007/066/4. ACIAR. Canberra, Australia.

Concepcion, S.B., Digal, L. and Uy, J. 2006. Keys to inclusion of small farmers in the dynamic vegetable market: The case of NorminVeggies in the Philippines. Recovering Markets Innovative Practice Series, IIED, London. 
Cramb, R. and Culasero-Arellano, Z. 2003. Landcare in South Cotabato. 2003. Philippines-Australia Landcare Project Evaluation Report No. 1

Cramb, R. 2006. Philippine -Australia Landcare Project Working Paper \# 4 . Rob. Social Capital and Soil Conservation: Evidence from Barangay Ned. Working Paper Number 4

CRS-Philippines. 2007. The Clustering Approach to Agroenterprise Development for Small Farmers: The CRS- Philippines Experience. A Guidebook for Facilitators. Davao City, Philippines.

Czerniawski, R. 1986. Cluster Marketing: An alternative approach to marketing planning and implementation.

Montiflor, M.O, Batt, P.J and Murray-Prior, R. 2008. Socioeconomic impact of Cluster Farming to Smallholder Farmers in Southern Philippines. In Batt, P.J. (ed), Proceedings of an International Symposium on the Socio-economic Impact of Modern Vegetable Production Technology in Tropical Asia. Acta Hort 809: 193-200.

Philippine-Australia Landcare Project Working Paper \# 15. Agro-enterprise and microfinance: Linking Landcare farmers to regional markets in Barangay Ned.

Shepherd, A. 2007. Approaches to Linking Producers to Markets. FAO Rural Infrastructure and Agro-Industries Division, Rome.

http://www.fao.org/ag/ags/subjects/en/agmarket/linkages/agsf13.pdf 